\title{
IMPLEMENTATION OF INFORMATION TECHNOLOGY AND INFORMATION SYSTEMS IN Commercial Companies Of The City Of Pau DOS FERROS - RN
}

\author{
Dyego Magno Oliveira Souza ${ }^{1}$, Déborah Assunção da Silva Alves ${ }^{2}$, José Eliomar \\ Rabelo $^{3}$, Adriano David Monteiro de Barros ${ }^{4}$, Lauro César Bezerra Nogueira ${ }^{5}$ \\ ${ }^{1,2,3}$ Graduating in Information Technology, Federal Rural University of the Semiarid \\ (UFERSA), Campus Pau dos Ferros, Pau dos Ferros, RN, Brazil. \\ ${ }^{4,5}$ Professor of Federal Rural University of the Semiarid (UFERSA), Campus Pau dos \\ Ferros, Pau dos Ferros, RN, Brazil.
}

\begin{abstract}
This paper had as approach a study about the use of IT resources in three different small, medium and large transport companies of the city of Pau dos Ferros - RN. The collected data allowed the knowledge of the main technological resources used in the internal structure of each company and their influence on the internal decision-making processes. When analyzing the resources used by the organizations, a certain similarity was identified in the types and a difference in the Information Systems used. The enterprises, named here as A, B and C, use the softwares SYSPDV, SoftCom and CissPoder, respectively. It was also identified that the small enterprise $A$ does not use all the functionalities of the Information System employed, while the large enterprises $B$ and $C$ explore all the capacities of the IS in the company internal structure.
\end{abstract}

\section{KEYWORDS}

Information Technology, Administration, Information Systems, Management.

\section{INTRODUCTION}

The extremely competitive scenario, in which many companies are inserted, acts as an important factor for the adoption of viable measures to the capacity to differentiate themselves from the competitors. The use of Information Technology (IT) as well as Information Systems (IS), in this context, is taken as a crucial strategic resource for the business survival [16].

The use of IT allows the organizations to increase their capacity to expand the internal structure, directly impacting their organizational performance, as it seeks to acquire, manipulate and communicate relevant information to their survival. In order to this objective be achieved - which makes the use of IT beneficial - it is necessary to define the forms of organization, productive systems and their management form [8].

The Companies with a fully computerized internal structure have great advantages over those that do not use such resources. The effective and efficient functioning of technological resources, especially information systems, provides to the user organizations, the time optimization, easy 
obtaining and easy access to crucial and important information, future data forecasts (possible profitability rates, for example), higher productivity, among several other aspects capable of contributing strongly, to reach the success and survival in the commercial scenario in which the companies are inserted [4] [16].

The IT should not be seen as something superfluous to the companies, but as a strong need. The automation of activities, that were previously manual activities, is a great competitive advantage, since modern information technologies, especially information systems, contribute to the quality improvement of several sectors and bring more reliability and better management of the information to be treated, greatly aiding in decision-making processes. For this purpose to be achieved, the use of technological resources must be linked to the company's business strategy [8].

In this study the use of IT will be approached in three different small and large companies of the commercial area of the city of Pau dos Ferros - RN, in order to demonstrate the benefits of the use of technological resources in the internal structure of the business and to point out its influences in decision-making. A study will also be carried out on the different information systems employed in the internal structure of the visited companies. This work is structured, firstly, in the definition of the main concepts that permeate the study theme - Information Technology Management and Information Systems, so that the main technological resources present in each visited enterprise can be listed and discussed more in-depth.

\section{THEORETICAL REFERENCE}

\subsection{INFORMATION TECHNOLOGY MANAGEMENT}

One of the great vectors of the transformations in the competitive scenario is the continuous evolution of the technology that, due to its great spread, has affected to a significant extent all the human activities. Among the new technologies, IT stands out, which has become an important competitive component for organizations [1].

Information Technology in companies can be conceptualized as "the set of knowledge and techniques used to operationalize the activities of the organizations, so that their objectives can be sought" [8].

As regards the link between technology and strategy, the creation and renewal of competitive advantages, considered as necessary factors for the survival of companies, combined with the use of technology, appear as a deterministic factor in the search for peculiarities that positively differentiate them from their competitors [22].

A fully computerized environment, and its effective and efficient operation, brings to the companies great advantages over their competitors, such as: time optimization, ease of access, greater information retrieval, future forecasts of data with greater reliability, higher productivity, and other benefits, which strongly contribute to its internal structure [4].

"The advent of new technologies has brought immeasurable benefits to the business operations and communication of organizations, allowing the circulation and storage of useful information to companies" [17]. But in order for the benefits of using IT to be obtained, it is necessary for the company to have a consolidated and well-defined internal structure. A maturity model of organizational evolution is defined, comprising five dimensions [24]. 
The dimension of vision and orientation is related to the goals the organization wants to achieve and these goals are directly linked to the available budget and the objectives to be achieved. The process dimension refers to how the organization is structured to achieve its objectives. The people dimension refers to how professionals interact in the organization. [..] The cultural dimension refers to the set of ideas, values, beliefs, practices and expectations that are shared among the people in the organization. The technological dimension deals with the existence of a global IT architecture integrated with people and processes [24].

The technological dimension, the last aspect of the maturity model of organizational evolution, is intertwined with IT management - and being integrated with people and processes, changes may be necessary [24]. The changes made in hardware and software are managed and conducted to achieve cost satisfaction, risk reduction and attention to business needs and pre-established objectives, providing them with a high degree of confidence and optimization [10].

Lower costs for technology acquisitions lead many companies to invest in this sector, often in a rampant and disorganized way. Considering only the competitive advantage, investments are made without taking into account the real needs of the business environment. Inadequate technological choices and lack of prior planning have a high possibility of resulting in excessive costs and difficult return, underutilization of these technologies and losses of competitiveness [4] [16].

With a prior and efficient planning that takes into account the individual characteristics of the company, the adoption of new technologies can be extremely beneficial. The use of technologies contributes to cost reduction, productivity gains, prospecting new markets, improving customer and supplier relationships, and finding and updating market information. [17]

"IT is not only a tool used to automate existing processes but is also a facilitator of organizational changes that can lead to additional productivity gains" [3]. "Given this, it is essential that the use of IT tools in micro and small companies is adequate to the real needs of the business, aiming the continuous improvement of their processes" [16].

With the low cost of many technologies, numerous companies have realized that it is more advantageous to exchange large cabinets, filled with paper documents, for computers [2].

Information Technology is not something superfluous to the companies, but a necessity for all, and can become a great competitive advantage, since modern information and communication technologies can improve the quality of several sectors. However, its use must be in line with the company's business strategy [8]. The strategic use of information and IT, is essential for SMEs to compete more evenly, promoting, in addition to more sustainable growth, their survival in the market [18].

"Therefore, the great importance that IT products and services present to the economic activities of globalized markets is clear, particularly to find innovations that allow companies to compete successfully" [12].

A large number of organizations from the most varied sectors of the economy have relied on Information Technology to carry out many of their operations [11]. One of the many IT resources that many companies rely on is the Information System, which is conceptualized in the next topic.

\subsection{INFORMATION SYSTEM}

"An Information System (SI) is a set of interrelated components that collect, manipulate and disseminate data and information to provide a feedback mechanism to achieve a goal" [21]. 
Information Systems have information about people, environments, and external and internal elements of the organization. Thus, it is asserted that data are sequences of non-polished facts and information are data organized and ordered in a way that means something to the recipient. Once systems were used specifically for the processing of operational information. Nowadays they analyze and control operational information, allowing information management, using it to plan and support strategic management [14].

The term Information System is defined as the computational tool with the capacity to transform data into information, influencing the decisions made by the company, aiming at its administrative security. It is appropriate to affirm that the optimization of the expected results becomes the great objective to be achieved with the use of IS in business environments. Implementing them in the internal structure of the business is essential for the acquisition and management of competitive advantages, which brings out the enterprise [14].

The set of computational systems used by an organization can perform some or all of a company's tasks. Its use evidences the metamorphosis of manual activities, with great susceptibility to errors, for its automation, which will be in charge of software with great capacity to process the vast amount of information contained in the organization of a company [23].

"Computers and information systems are constantly changing the way organizations conduct their business. Information has value, and the commerce deals with the exchange of information instead of with tangible goods "[21].

\section{METHODOLOGY}

The respective paper is characterized by a qualitative study, which aims to produce information of a profound and illustrative nature, capable of fostering new information about the problem studied. The data collected in this type of research are non-metric (raised and interacting), using different approaches [9].

One of these approaches is the questionnaire, considered as a set of issues designed to generate data necessary to verify pre-defined project objectives. There are no standard methodologies for questionnaires, according to current scientific methodologies, but there are recommendations aimed at guiding researchers during the elaboration of their scientific work [7] [13].

Regarding to the objectives, the research is descriptive, since it required a critical analysis of the information obtained in the projects $\mathrm{A}, \mathrm{B}$ and $\mathrm{C}$, collected through a subjective questionnaire. In general, questionnaires are used to obtain data, on a large scale or not, for qualitative analysis. In such cases, it is up to the applicator to write or respond in writing to a series of carefully crafted questions based on the research objective. Responses are usually limited and must understand all the possibilities that encompass the reality of the interviewee, in order to bring more reliability to the information collected. In this study, in addition to the alternatives present in each questioning, it was opened space so that the interviewees could also list the main tools implemented in their businesses [7] [9] [13].

The results to be discussed and presented in the subsequent sections were the result of a survey carried out directly on 10/31/2016 at the commercial center of the city of Pau dos Ferros, located in the state of Rio Grande do Norte. The applied research was developed from a questionnaire that included information about the presence of some of the IT resources in the internal commercial scope, its listing (when existing), implementation and impacts on the business decision-making processes. In order to characterize each establishment, information was also 
International Journal of Software Engineering \& Applications (IJSEA), Vol.8, No.5, September 2017

collected regarding the area of performance and size of the company. Below, in Tables 1, 2 and 3 the data referring to the characterization of the visited enterprises.

Table 1. Data from the first company

\begin{tabular}{|c|c|}
\hline \multicolumn{2}{|c|}{ Company A } \\
\hline Field of activity & Retail business \\
\hline Size & Small business \\
\hline
\end{tabular}

Table 2. Data from the second company

\begin{tabular}{|c|c|}
\hline \multicolumn{2}{|c|}{ Company B } \\
\hline Field of activity & Retail business (branch office) \\
\hline Size & Large-sized company \\
\hline
\end{tabular}

Table 3. Data from the third company

\begin{tabular}{|c|c|}
\hline \multicolumn{2}{|c|}{ Company C } \\
\hline Field of activity & Retail business (branch office) \\
\hline Size & Large-sized company \\
\hline
\end{tabular}

The questionnaires were applied with the managers of each establishment and with the presence of the three authors of this work, who were dedicated to guide the questions to the interviewees.

\section{RESULTS AND DISCUSSIONS}

For a better discussion of the results obtained, we will first present the data referring to the listing of the IT resources applied in the internal structure of the visited enterprises. Next, a study will be done on the different Information Systems used by each business, its characteristics and use.

\subsection{IT RESOURCE LISTING}

The data collected with the visit to companies A, B and C, objects of study of this work, fomented the construction of Table 4, which lists the main resources employed in its internal structures.

Table 4. List of technological resources in the companies visited

\begin{tabular}{|c|c|c|c|}
\hline & $\begin{array}{c}\text { COMPANY } \\
\text { A }\end{array}$ & $\begin{array}{c}\text { COMPANY } \\
\text { B }\end{array}$ & $\begin{array}{c}\text { COMPANY } \\
\text { C }\end{array}$ \\
\hline Computers use & Yes & Yes & Yes \\
\hline Operational System & Windows 7 & Windows 7 & Windows 7 \\
\hline Network Type & LAN & WAN & WAN \\
\hline Internet Access & Yes $^{1}$ & Yes $^{1}$ & Yes $^{1}$ \\
\hline Website & No & Yes $^{2}$ & Yes $^{2}$ \\
\hline Information System & SYSPDV & SoftCom & CissPoder $^{2}$ \\
\hline
\end{tabular}

The TIC Companies survey, operative since 2005, measures the presence of IT in companies with 10 or more employees. Its purpose is to draw up a research line on access to infrastructure, the use and ownership of modern technology by business sectors, in order to map the perception of

\footnotetext{
${ }^{1}$ Access type: cable connection.

${ }^{2}$ It has a website, but belongs to the entire network in which it is affiliated.
} 
the benefits associated with the enterprise. Published annually since 2005, the 2014 edition, the last available so far, showed that of the 6,429 companies with 10 or more persons employed, $99 \%$ used computers in their activities in 2011,98\% used computers in their activities in the year of 2012 and $97 \%$ also made use of the technological tool in 2013 [15] [19]. The study carried out in this study showed that, of the three companies interviewed, all (100\%) used/used computers in their internal activities. Despite the slight reduction in the percentage indicated by the TIC Companies survey, it is evident that in the commercial center of the city of Pau dos Ferros, the enterprises have joined the use of computers.

The data obtained from this work also showed that the companies interviewed use a closed source operating system, such as case Windows 7, present in the three projects interviewed, according to Table 4. There is also a great resistance in using operating systems of open source, such as Linux. According to the TIC Companies survey (2014), out of a total of 6,225 companies that reported using a computer with 10 or more people employed, $73 \%$ said in 2013 they would use closed source operating systems, such as Windows, which had a unanimous presence in the data of the research carried out in the city of Pau dos Ferros [15].

In relation to the type of network, there are two types that stand out. The LAN, acronym for Local Area Network, refers to computer networks constrained to a well-defined physical location. It is the most common type of network in homes, offices and businesses in the same location. Its limitation comes from the common network mask, which ends up restricting an IP range. According to data from the survey carried out with the companies of the commercial center of the city of Pau dos Ferros, only company A reported making use of this type of network in its structure. Being a local and non-affiliated business justifies the use of LAN. According to the TIC Empresas survey (2014), of the 6,225 companies that reported using a computer, with 10 or more people employed, $74 \%$ reported using the wired LAN and $84 \%$ reported using the wireless LAN. It was observed that in company A, the target of this discussion, the LAN is wired, which makes the connection between the various computers employed in the business [15].

Continuing with the discussion, Table 4 shows that companies $\mathrm{B}$ and $\mathrm{C}$ make use of the WAN network. Acronym for Wide Area Network, it refers to networks that cover a larger physical area. It is the most common type of network in a city, state or even a country. It is extremely necessary for different branches, located in different geographic areas, to traffic expressive amounts of information among themselves. Since the B and C companies are subsidiaries of a larger network, the use of the WAN network in its internal structure is justified. According to the TIC Companies survey (2014), of the 6,225 companies that reported using a computer, with 10 or more persons employed, 28\% stated that they would use an extranet network in the organization [15].

Table 4 also showed that all the companies interviewed had access to the internet through a cable connection. According to the TIC Companies survey (2014), out of a total of 4,728 companies with Internet access, with 10 or more employees, in the year 2013, 54\% reported using a cable connection, $20 \%$ radio connection, $64 \%$ connection via telephone line and $8 \%$ satellite connection [15].

The use of websites ensures greater proximity to customers and potential business customers and allows for greater dissemination of the products offered by the venture, as well as the promotions in force in the establishment. According to the survey carried out with some companies of the commercial center of the city of Pau dos Ferros, only company A reported not making use of any website or virtual page to promote the business, while companies $\mathrm{B}$ and $\mathrm{C}$ have a website however, to the local establishment, but to all branches in different geographic areas. According to the TIC Companies survey (2014), from the total of 6,159 companies that reported having Internet access, with 10 or more persons employed, 56\% stated in the year of 2013, the existence of a business website [15]. 
Regarding to information systems, the companies interviewed have a specific type, which will be discussed more in-depth in the later topics of this paper.

\subsection{INFORMATION SYSTEMS}

\subsubsection{COMPANY A}

It has been reported that the internal business scope of the business is governed by the SYSPDV software. Some of its main features for the market segment, according to the developer's website, are listed: control of all sectors of the supermarket; monitoring all cash operations, on-site or by remote access; has Electronic Funds Transfer (EFT) and cellphone recharge; access to sales performance via mobile devices; facilitates the purchasing process; controls financial movements; exports files in standard SPED, SINTEGRA, CAT, and SEF 11; monitoring of all POS operations, local or remote; PDV online / offline - the PDV does not stop even with the server off; agility in the entry of invoices (import of NF-e via XML or key); identification of products without sales; allows up to 3 prices per product and each price with its discounts; credit limit per customer; configuration of access levels by user group; automatic backup scheduling; sending of POS alert emails; report of occurrences in the POS; Audit history [5].

Despite the big capacity of the SYSPDV software, its use is still limited within the commercial scope of the Mercantil Cidade. There is also an insistence on carrying out, in a manual way, the control of the cash and stock of products. It is important to emphasize that the access to the software's functionalities is negotiated directly with the customer in the process of product acquisition. The greater the offer, the greater the range of features available.

\subsubsection{COMPANY B}

It has been reported that the internal commercial scope of the electric furniture store is governed by SoftCom software. Some of its main features for the market segment, according to the developer's website, are listed: database for registering more than 4 thousand items and customers; entry note registration with XML, which allows time gain and accounting integration; stock counting; support QR code technology; box with permission to all credit cards in force in the market; financial manager; duplicate printing for forward sales; Electronic Invoice issuance; integration with accounting, SPED Fiscal and Pis Cofins [20].

It was evidenced that enterprise B, different from enterprise A (see topic 4.2.1), uses all the functionalities of the information system employed in its commercial scope. The software is used to issue electronic invoices, delivered to customers after the purchase of a product; payments made on cards - of all flags, according to the manager; personal data of customers, which are stored in a database and can be easily queried; control of customers in debt with the store; consultation and counting of the stock of furniture and household appliances in the local stock mainly in order not to materialize the sale of a missing product.

\subsubsection{COMPANY C}

It has been reported that the internal business scope of the business is governed by CissPoder software. Some of its main features for the supermarket segment, according to the developer's website, will be listed.

For sales: own card management (similar to credit card); registration of promotions and offers with start and end dates; automatic discount for customers; special discounts for VIP's; VIP card, the customer is priced differently in a gram of products; price quotation with competitors; price 
list registration for commercial agreements with special clients; price quotation with competitors; integration with e-commerce (virtual commerce). For stock: stock control with barcode reader; process of blind-entry with the wi-fi data collector; register of various stock locations; control of exchanges by supplier; inventory audit with wi-fi collector. For profitability: analysis of the profitability of the company by profit center (business); management by category; suggestion of the sale price through SEBRAE's personalized formulas; control of the production of own products; system that warns if the product was registered with a price lower than some cost; customized accounting statements; control of trade agreements with suppliers and management of subsidies; profitability report by division / section / group / subgroup and results center. For default: automatic calculation of the credit limit per customer; automatic blocking for customers who exceeded the credit limit; automatic calculation of interest; registration and blocking of stolen checks; automatic issuance of bank vouchers; sending and receiving bank remittance; registration of the signature and the photo of the client and its authorized; form of payment by customer. For financial control: accounts payable and receivable; check printing; grouping of duplicates; control of bank accounts; receipt printing. For cash flow: bank reconciliation; control of advances to employees, customers and suppliers; purchasing budget; control of cash flow with future provisioned balance; holiday provision, 13th, insurance, investments, etc. For the client: option to implement own card; price research with competitors; consumer satisfaction survey; delivering efficient and agile through the management of advanced delivery logistics. For security: control access to system processes per user; control of access to subsidiaries by user; access control, process release and closing of sales by biometrics; and automatic backup [6].

The software used in the subsidiary of Pau dos Ferros is the most robust among those cited in this work. Its range of functionalities is great and allows its client to maintain the processes necessary for its management in an efficient and profitable way. Being a well-known network in the northeastern region, it is justifiable to use an information system full of capabilities.

\section{CONCLUSION}

There is an expressive similarity between the IT resources employed in the internal structures of the visited companies. All of them, as demonstrated, use computers, have access to the Internet, make use of the network (LAN and WAN) and an Information System capable of strongly influencing decision-making and assisting in their daily activities. It was also reported that for enterprise A, small business, all functionalities of the employed SI (SYSPDV) are not used, whereas in enterprises B and C, large companies, the software used (SoftCom and CissPoder) have all their features explored.

The software has only one essence, but it is the customer who determines its functionalities, varying the price. Perhaps for fear of investing and not getting return, most small businesses, as was the case of company A, opt for something simpler and not so robust. By trying to save on an effective investment, it also ends up curbing its profit margins, strongly associated with IT, which by the way is the key to success for optimization and automation in the processes that accumulate a lot of time and work carried out by employees and partners of the company.

Stair and Reynolds argue that "[...] computers and information systems will continue to change our society, our business, and our lives" [21]. A few years ahead, that is easily seen in everyday life. Technology has become extremely necessary to modern man and his business. In view of the above, and regarding to the statement mentioned, it can be highlighted the use of technological resources by enterprises A, B and C, which are strongly intertwined with their structure, acting as main components. 
International Journal of Software Engineering \& Applications (IJSEA), Vol.8, No.5, September 2017

\section{REFERENCES}

[1] C. S Albano, “Adoção de Novas Tecnologias da Informação: um Estudo de Problemas e Ações nas Cooperativas Agropecuárias do Rio Grande do Sul”. In: Encontro Anual da Associação Nacional dos Programas de Pós-Graduação em Administração, 2001, Anais... Campinas, São Paulo. 2001.

[2] R. Baldam,. R. Valle, M. Cavalcanti, A. S. Siqueira, G. Malamut, M. Abreu, R. Seldin. S. Barbará, T. Cruz, "Que Ferramenta devo Usar? Ferramentas tecnológicas aplicáveis a: Gestão de Empresas, Racionalização do Trabalho, Gerenciamento do Conhecimento". Rio de Janeiro: QualityMark, 2005, 216 p.

[3] M. Beltrame, A. Maçada, "Validação de um Instrumento para medir o Valor da Tecnologia da Informação (TI) para as organizações”. Organizações em contexto, v.5, n.9, p.1-23, 2009.

[4] L. C. Beraldi, E. Escrivão Filho, "Impacto da Tecnologia de Informação na Gestão de Pequenas Empresas”. Ci. Inf, Brasília, v. 29, n. 1, p. 46-50, abr 2000.

[5] Casa "Sistemas Magalhães, SYSPDV". Disponível em: <http://www.casamagalhaes.com.br/sistemas/syspdv>. Acesso em: 16 dez. 2016.

[6] Ciss, "Maximize a Gestão do seu Supermercado". Disponível em: <http://ciss.com.br/cisspodersoftware-para-supermercados>. Acesso em: 16 dez. 2016.

[7] Departamento de Informática e Estatística. "O Uso de Questionários em Trabalhos Científicos". Disponível em: <http://www.inf.ufsc.br/ vera.carmo/Ensino_2013_2/O_uso_de_questionarios_em_trabalhos_cientifi cos.pdf>.Acesso em: 27 jan. 2016.

[8] F. da S. Duarte, et al., "A contribuição da TI como Ferramenta na Gestão de Negócios: um Estudo de Caso de uma Empresa no Ramo Tecnológico Localizada no Município de Dom Pedrito/RS”. TecnoLógica, v. 18, n. 2, p.103-114, 2015.

[9] T. E. Gerhadt, D. T. Silveira, "Métodos de Pesquisa". Porto Alegre: Editora da Ufrgs, 2009. Disponível em: <http://www.ufrgs.br/cursopgdr/downloadsSerie/derad005.pdf>. Acesso em: $12 \mathrm{dez}$. 2016.

[10] S. Hagen, A. Kemper, "Towards solid IT change management: automated detection of conflicting IT change 2011. plans”. Disponível em: <http://wwwdb.in.tum.de/research/publications/conferences/IM2011.pdf>. Acesso em: 18/01/2017.

[11] G. L. Lunardi, A. C. G. Maçada, J. L. Becker, "Gerenciamento dos Investimentos em Tecnologia de Informação (TI): um Estudo Baseado em Mini-Casos”. SINERGIA-Revista do Instituto de Ciências Econômicas, Administrativas e Contábeis, v. 16, n. 2, p. 21-28, 2013.

[12] R. de O. Moraes, F. J. B. Laurindo, "Maturity and Performance in Information Technology Project Management”. Journal Of Technology Management \& Innovation, [s.1.], v. 8, p.5-6, 2013. SciELO Comision Nacional de Investigacion Cientifica Y Tecnologica (CONICYT). $<$ http://dx.doi.org/10.4067/s0718-27242013000300003>.

[13] G. L. R. Moysés, R. G. Moori, “Coleta de Dados para a Pesquisa Acadêmica: um Estudo sobre a Elaboração, a Validação e a Aplicação Eletrônica de Questionário”. In: Encontro Nacional de Engenharia de Produção ENEGEP, 27., 2007, Foz do Iguaçu, Pr. Congresso. Foz do Iguaçu, Pr: Enegep, 2007. p. 56 - 67.

[14] K. I. de A. Pereira, et al. "Sistemas de Informação: um Estudo de Caso em uma Unidade Suplementar da Universidade Federal do Rio Grande do Norte”. R. Gestão Univ. Amer. Lat. Gual, [s.1.], v. 8, n. 4, p.189-199, 15 dez. 2015. Universidade Federal de Santa Catarina (UFSC). <http://dx.doi.org/10.5007/1983-4535.2015v8n4p189>. 
International Journal of Software Engineering \& Applications (IJSEA), Vol.8, No.5, September 2017

[15] Pesquisa Anual do Uso de TI nas Empresas, GVcia, FGV-EAESP, 27ª edição, 2016. Disponível em: $<$ http://eaesp.fgvsp.br/ensinoeconhecimento/centros/cia/pesquisa>. Acesso em: 15 nov. 2016.

[16] A. de V. Pinto, "O Impacto da Adoção de Tecnologias da Informação no Desempenho Organizacional das Micro e Pequenas Empresas”. 2016. 82 f. TCC (Graduação) - Curso de Administração, Departamento de Ciências Administrativas, Universidade Federal do Rio Grande do Sul, Porto Alegre, 2016.

[17] A. B. da Silva, Â. de S. Brasil, L. M. dos S. Alvarenga, S. M. dos Santos, "Desafios Enfrentados Pelas Micro e Pequenas Empresas no Brasil”. Conexão Eletrônica, Três Lagoas, MS, v. 12, n. 1, 2015.

[18] R. C. D. C. Silva, M. C. Dos Reis, "Pesquisa sobre a utilização das tecnologias da informação e dos recursos de internet: micro e pequenas empresas do comércio varejista de Londrina". Revista de Ciências Jurídicas e Empresariais, v. 9, n. 1, 2015.

[19] É. S. Siqueira, C. A. de Souza, A. B. N. Viana, "Uso da Tecnologia de Informação em Empresas de Pequeno e Médio Porte: uma análise a partir dos dados da pesquisa "TIC Empresas de 2011". In: Conf-Irm 2013 International Conference on Information Resources Management. 2013. p. 1-14.

[20] Softcom Tecnologia. Loja Varejo. Disponível em: <http://www.softcomtecnologia.com.br/solucaointerna.php?sol=10>. Acesso em: 16 dez. 2016.

[21] R. M. Stair, G. W. Reynolds, "Princípios de Sistemas de Informação”. Ed.: Cengage Learning. 2011.

[22] P. R. G. Torquato, G. P. Silva, "Tecnologia e estratégia: uma abordagem analítica e prática”. São Paulo: Revista de Administração, v. 35, n.1, p.72-85, jan./mar 2000.

[23] E. Turban, L. Volonino, "Tecnologia da Informação para Gestão: Em Busca de um Melhor Desempenho Estratégico e Operacional”. Bookman Editora, 2013.

[24] M. A. V. Vitoriano, J. Souza Neto, "Information technology service management processes maturity in the Brazilian Federal direct administration". Journal Of Information Systems And Technology Management, [s.1.], v. 12,n. 3, p.663-686, 1 jan. 2016. TECSI. <http://dx.doi.org/10.4301/s1807$17752015000300009>$.

\section{ACKNOWLEDGMENT}

This Study Was Made Possible By The Contributions Of The Three Companies Interviewed, Which Provided Us With Information About Its Internal Structure. To The Three, Our Most Sincere Thanks!

\section{AUTHORS}

Dyego Magno Oliveira Souza Is Undergraduate From The Bachelor's Degree In Information Technology By Federal University Of The Semiarid (UFERSA), Campus Pau Dos Ferros, RN, Brazil. Passionate About Programming, He Is Currently A PIBICCnpq Fellow In The Amesy Project, Which Aims To Improve Physical-Cyber Medical Systems.

Déborah Assunção da Silva is an undergraduating from the Bachelor's degree in Information Technology by Federal University of the Semiarid (UFERSA), campus Pau dos Ferros, RN, Brazil.

José Eliomar is an undergraduate from the Bachelor's degree in Information Technology by Federal University of the Semiarid (UFERSA), campus Pau dos Ferros, RN, Brazil.
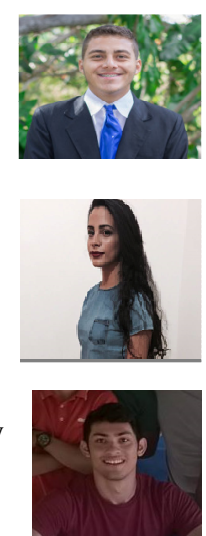
International Journal of Software Engineering \& Applications (IJSEA), Vol.8, No.5, September 2017

Adriano David Monteiro de Barros is Master in Production Engineering from the Federal University of Paraíba, in the line of research in Technology, Work and Organizations. Specialist in Administrative Law and Public Management by FIP, Specialist in Democracy and Fundamental Rights by UEPB, Specialist in Health Management by UEPB, Specialist in Human Rights by the UFCG, Bachelor of Administration by the Mauricio de Nassau Faculty and Bachelor of Public Administration by UEPB.

Lauro César Bezerra Nogueira is professor at the Multidisciplinary Center of Pau dos Ferros of the Federal Rural University of the Semiarid and professor of the Graduate Program in Economics of the State University of Rio Grande do Norte. Graduated in Economic Sciences from the State University of Rio Grande do Norte. Msc. in Economic Sciences from the Federal University of Pernambuco (2009/2010). Dr. in Economics from the Federal University of Paraíba, Brazil.
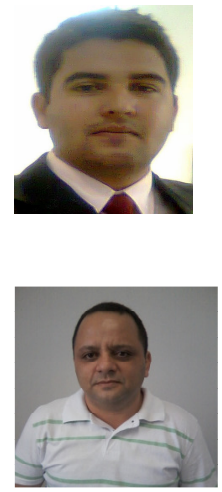